\title{
Izometric effort in the balance stance of handball throw
}

\section{Alexandru Andrei GHERMAN1, Leon GOMBOȘ ${ }^{2}$, Adrian PĂTRAȘCU ${ }^{3}$, Sergiu POP 4}

\begin{abstract}
Postural balance plays an important role in high performance sports. The line between success and failure may be decided at such a small scale. In handball, postural balance may affect the accuracy of every technique that a played use, especially the throwing of the ball towards the goal. Our study aimed to identify the degree of influence that izometric effort has over the balance stance during a handball throw. Subjects: $2101^{\text {st }}$ year students from the Faculty of Physical Education and Sport, Babeș-Bolyai University from Cluj-Napoca, were involved in this study. The subjects were both male and female, with the ages between 18 and 21 years old, with and without former performance athlete background. Materials: We've conducted the balance test using the AMTI NETforce BP 400600 force platform and the actual isometric exercises were completed in the same laboratory. Two types of planks and a half-squat were used as the isometric exercises. Results: There was no significant statistical difference between the balance variables before and after isometric exercises while holding the ball in hand. There was a significant statistical difference between the displacement before and after for the position without the ball. Conclusion: There is no impact of the isometric effort over the balance stance while holding the handball ball in the throwing position. We've identified a strong relation between the isometric effort and the balance stance without the ball in hand.
\end{abstract}

Key words: handball, balance, isometric, effort, throwing stance

\section{Rezumat}

Echilibru postural joacă un rol cheie în sportul de mare performanță. Granița dintre succes si eșec se poate rezuma la acest mic aspect. În handbal echilibrul postural poate afecta acuratețea fiecărei tehnici folosite de un jucător, cu predilecție în aruncarea mingii spre poartă. Obiectul studiului nostru a fost să identifice gradul de influență pe care efortul izometric îl are asupra echilibrului în timpul aruncării mingii de handbal. Subiecții: în studiu au fost cuprinși ca eșantion 210 studenți ai anului I din cadrul Facultății de Educație Fizică și Sport, Universitatea Babeș-Bolyai Cluj-Napoca. Subiecții au fost atât de gen masculine cât și feminin, vârsta fiind cuprinsă între 18-21 de ani, nefiind sportive de performanță. Materiale: Am efectuat testul folosind platforma AMTI NETforce BP 400600 în combinație cu exerciții de izomerie în același laborator. Două tipuri de exerciții de tip planks și half-squat au fost folosite în exercițiile izometrice. Rezultate: Nu s-au evidenţiat diferențe de natură statistică între variabilele echilibrului între și după exercițiile de izomerie ținând mingea în mână. Pe de altă parte s-a constatat o diferență remarcabilă de natură statistică între deplasarea înainte și după fără minge în mână. Concluzii: nu s-a remarcat un impact major al efortului izometric asupra echilibrului ținând mingea de handbal în mână în poziție de aruncare. Am constatat în schimb o legătură strânsă între efortul izometric și echilibrul static fără minge în mână.

Cuvinte cheie: : handbal, echilibru, izometrie, efort, poziție de aruncare.

\footnotetext{
${ }^{1}$ Lecturer, Babeș-Bolyai University, Cluj-Napoca, Romania, Faculty of Physical Education and Sport, e-mail: alexandru.gherman@yahoo.com

2 Prof., Babes-Bolyai University, Cluj-Napoca, Romania, Faculty of Physical Education and Sport

${ }^{3}$ PhD Candidate, Babeș-Bolyai University, Cluj-Napoca, Romania, Faculty of Physical Education and Sport

${ }^{4}$ Asist Prof., Babes-Bolyai University, Cluj-Napoca, Romania, Faculty of Physical Education and Sport
} 


\section{Introduction}

Charts, tables, graphs will be placed here in the document. Strength is an important prerequisite for athletic performance. This is especially true in activities that require the application of force to an eternal object such as in the shot-put, javelin throw, discus throw, or hammer throw. The importance of strength in any athletic sport varies in degree and depends on the level of strength needed for maximum development of skill and movement. Once this level (theoretical) is gained, any additional strength will probably result in improved performance.

Training isometrically has certain advantages over isotonic training or weigh training. Little or no equipment is needed and the same muscles can be exercised in a small fraction of the time required for weight training. Since little fatigue is developing isometric training, work-out sessions may be conducted during the sport without deleterious effects to the participants [1].

In many sports branches, the over arm throwing is considered to be the most important skill. The throwing performance depends on the player's optimal coordination of his/her body to create the maximum velocity. The player, when she/he is ready for throwing, has to use all body segments from ankle to wrist. Toyoshima et al. have indicated that the $53,1 \%$ of the throwing velocity springs from arm movement and the $49,9 \%$ of it is dependent on stepping and body rotation [2].

In the acceleration stage of the throw, the arm performs the whip motion while passing from the external rotation(ER) position to the internal rotation (IR) position. [3] suggested that, as the shoulder rotational range of motion increases, the efficiency of the athlete's internal rotator muscles will increase and the velocity of the ball will be higher [3, 4, 5], and [6] examined internal and external range of motion and strength in throwing motion in baseball $[4,5,6]$.

In these studies, they have found that the thrower should produce a considerable amount of torque during the IR in order to throw the ball accurately and with a high speed. Handball necessitates several skills and physical traits special to the game. The goal, which is the essential to win in handball, depends on a quality throwing [7]. Thus, throwing is a crucial skill in handball as it is the case in several other sports branches [7, 8]. The goal is achieved expeditiously before defenders and the goalkeeper block. When the kinematic chain during the throwing is observed to give the ball maximum velocity; firstly, the shoulder, then the elbow, and finally the wrist reaches the maximum velocity [7]. In handball, the goals coring ability substantially depends on ball velocity and throwing accuracy. Throwing velocity and accuracy are the main performance parameters during the game in handball [9].

Researches on efficiently training the athletes by improving the capacity of coordination within the individual training are of great interest. The individualization of training for handball players is necessary due to the existent differences between tactical and technical content specific to the different game positions, but also to the high degree of difficulty of the technical execution [10].

In modern handball, athletes can play almost on any game position and so, they need more coordination to handle the technical and tactical actions specific to the game position that they play in, at a given time. The change of a game position should be fast and done by selecting and executing a quick and appropriate response to a stimulus via an efferent way, from the nerve centers to certain effectors [11, 12].

Systematic assessment of the isokinetic muscle strength of the lower extremities throughout the annual training cycle is crucial from a performance perspective for the optimization of the training process, as well as a health perspective regarding injury prevention.

Assessment by isokinetic dynamometry has been considered as the gold standard to provide an objective approach to diagnostics and simpler quantification of muscle strength. Most studies in handball female players have concentrated on concentric measurements. Based on these measurements, ipsilateral imbalances were described by the conventional hamstring to quadriceps ratio (H/QCONV) $[13,14]$.

In one study [15] is presented that fatigue-induced impairment in mechanical muscle function and reduced neuromuscular activity were demonstrated acutely following a simulated handball match. The decrease in MVC may potentially lead to impaired functional performance during tackling and in fights 
in the latter part of the match. Likewise, the reduced RFD likely will have a negative impact on fast movements like accelerations, sprints and side cutting. The reduced vertical JH potentially impairs the ability to block shots from attacking players and conversely shoot over the blocks during attack play. Based on these notions, future studies should be conducted to identify the specific neuromechanical and cellular origins of fatigue, while it would also be of great interest to investigate the impact of different resistance training regimes in increasing the fatigue resistance [15] during elite handball match playing.

\section{Hypothesis}

Isometric effort may influence the postural balance of a handball player during the shooting stance.

\section{Subjects}

In this study 210 subjects were involved from beginning to end. They were students from the $1^{\text {st }}$ year of studies from the Faculty of Physical Education and Sport, Babes-Bolyai University in Cluj-Napoca. They were between 19 and 21 years of age and out of them there were 57 females and 153 males.

All the subjects were briefed beforehand regarding what the experiment consisted of and what they were required to do. The subjects were assured that any personal information would not be made public and their personal data recorded will be analyzed under the cover of anonymity. Moreover, the subjects were instructed how to control social and routine aspects of their lives so that those variables would not interfere with the experiment's results. Also, after the briefing, the subjects were asked to confirm their understanding of what was required on a premade consent form.

\section{Methods and Materials}

Our study consisted of two main parts: the initial test and the final test. Both tests consisted of balance tests. The final test had, besides the balance test, isometric exercises that were done before each measurement.

The balance test was done using the AMTI NETforce platform BP400600. It is a force platform that measures the pressure force of the subject. Because of this it has the ability to register any variations or modifications regarding the center of pressure (COP), and, at its core, the movement of body's center of gravity. After the test, the platform's software allows us to visualize four parameters: length, area, velocity and displacement of the COP. Length is the distance in centimeters that the COP travels over course of the test.

Area is the surface in which the COP's movements are confined during the test. Velocity is the speed of variations of COP during the test.

Displacement is the straight-line distance from the starting position to the final one at the end of the test. Not to be confused with the trajectory.

The isometric effort consisted of three exercises: one for the upper body, one for the core and one for lower body. For the first one the subject was required to hold a half push-up stance for 20 seconds, for the second one a 30 second plank and for the final one a 30 second half-squat.

We measured, for each of the two balance tests, two postural stances: the final body position of the subject at the end of a simulated handball throw with and without the ball in hand.

The protocol for the first test, without the ball, was:

- 3 - 5 minutes explaining the test;

- 2 minutes preparation and getting used to the instrument;

- Calibration of the device;

- Measurement of the throwing position without the ball;

- Pause 10-15 seconds, and if not valid, repeat.

The protocol for the second test was similar, though it had some small differences:

- 10 second preparations - getting into position;

- Calibration of the device;

- Measurement of the throwing position with the ball;

- Pause 5-10 seconds, and if not valid, repeat. For the statistical analysis of the data we've used the SPSS v17.0 version of the software. A paired sample t-test was conducted for each balance parameter between the initial and final measurements. 


\section{Results}

Table No. 1 - Paired samples statistics

\begin{tabular}{|ll|c|c|c|c|}
\hline & Mean & N & $\begin{array}{c}\text { Std. } \\
\text { Deviation }\end{array}$ & $\begin{array}{c}\text { Std. } \\
\text { Error } \\
\text { Mean }\end{array}$ \\
\hline Pair & Displ_NB_Ini & 0.71451 & 210 & 0.356418 & 0.0246 \\
1 & Displ_NB_Final & 0.79849 & 210 & 0.387749 & 0.02676 \\
Pair & Area_NB_Ini & 9.69225 & 210 & 18.3611 & 1.26704 \\
2 & Area_NB_Final & 12.2806 & 210 & 22.43065 & 1.54786 \\
Pair & Velo_NB_Ini & 3.52136 & 210 & 3.707682 & 0.25585 \\
3 & Velo_NB_Final & 4.02504 & 210 & 1.331167 & 0.09186 \\
Pair & Length_NB_Ini & 35.2133 & 210 & 37.07675 & 2.55854 \\
4 & Length_NB_Final & 40.2503 & 210 & 13.31185 & 0.91861 \\
Pair & Displ_WB_Ini & 0.74487 & 210 & 0.462288 & 0.0319 \\
5 & Displ_WB_Final & 0.7908 & 210 & 0.330581 & 0.02281 \\
Pair & Area_WB_Ini & 12.5081 & 210 & 47.76238 & 3.29592 \\
6 & Area_WB_Final & 12.1834 & 210 & 14.45412 & 0.99743 \\
Pair & Velo_WB_Ini & 3.66422 & 210 & 3.074202 & 0.21214 \\
7 & Velo_WB_Final & 4.16338 & 210 & 4.639038 & 0.32012 \\
Pair & Length_WB_Ini & 36.6423 & 210 & 30.74181 & 2.12139 \\
8 & Length_WB_Final & 41.6342 & 210 & 46.39004 & 3.20122 \\
\hline
\end{tabular}

Table No. 2 - Paired sample t-test

\begin{tabular}{|c|c|c|c|c|c|}
\hline & & & $\mathrm{t}$ & $\mathrm{df}$ & Sig. (2- \\
\hline $\begin{array}{l}\text { Pair } \\
1\end{array}$ & $\begin{array}{l}\text { Displ_NB_Ini } \\
\text { Displ_NB_Final }\end{array}$ & - & $\begin{array}{l}- \\
2.31\end{array}$ & 209 & 0.022 \\
\hline $\begin{array}{l}\text { Pair } \\
2\end{array}$ & $\begin{array}{l}\text { Area_NB_Ini } \\
\text { Area_NB_Final }\end{array}$ & - & $\begin{array}{l}- \\
1.29\end{array}$ & 209 & 0.199 \\
\hline $\begin{array}{l}\text { Pair } \\
3\end{array}$ & $\begin{array}{l}\text { Velo_NB_Ini } \\
\text { Velo_NB_Final }\end{array}$ & - & $\begin{array}{l}- \\
1.88\end{array}$ & 209 & 0.062 \\
\hline $\begin{array}{l}\text { Pair } \\
4\end{array}$ & $\begin{array}{l}\text { Length_NB_Ini } \\
\text { Length_NB_Final }\end{array}$ & - & $\begin{array}{l}- \\
1.88\end{array}$ & 209 & 0.062 \\
\hline $\begin{array}{l}\text { Pair } \\
5\end{array}$ & $\begin{array}{l}\text { Displ_WB_Ini } \\
\text { Displ_WB_Final }\end{array}$ & - & $\begin{array}{l}- \\
1.15\end{array}$ & 209 & 0.251 \\
\hline $\begin{array}{l}\text { Pair } \\
6\end{array}$ & $\begin{array}{l}\text { Area_WB_Ini } \\
\text { Area_WB_Final }\end{array}$ & - & 0.09 & 209 & 0.926 \\
\hline $\begin{array}{l}\text { Pair } \\
7\end{array}$ & $\begin{array}{l}\text { Velo_WB_Ini } \\
\text { Velo_WB_Final }\end{array}$ & - & $\begin{array}{l}- \\
1.28\end{array}$ & 209 & 0.202 \\
\hline $\begin{array}{l}\text { Pair } \\
8\end{array}$ & $\begin{array}{l}\text { Length_WB_Ini } \\
\text { Length_WB_Final }\end{array}$ & - & $\begin{array}{l}- \\
1.28\end{array}$ & 209 & 0.202 \\
\hline
\end{tabular}

A paired-sampled t-test was conducted to compare the value of the initial displacement without the ball (Displ_NB_Ini) and the value of the final displacement without the ball (Displ_NB_Final) for the subjects. There was a significant difference in the scores of the initial test $(M=0.71451, S D=$ $0.356418)$ and of the final test $(M=0.79849, S D=$ $0.387749)$ conditions; $\mathrm{t}(209)=-2.31, \mathrm{p}=0.022$. These results suggest that the isometric effort the subjects undergone did affect the displacement of COP during the handball shooting stance without the ball. (Table 1 and 2)

A paired-sampled t-test was conducted to compare the value of the initial area without the ball (Area_NB_Ini) and the value of the final area without the ball (Area_NB_Final) for the subjects. There was no significant difference in the scores of the initial test $(M=9.69225, S D=18.3611)$ and of the final test $(\mathrm{M}=12.28064, \mathrm{SD}=22.430651)$ conditions; $t(209)=-1.288, p=0.199$. These results suggest that the isometric effort the subjects undergone did not affect the area of COP during the handball shooting stance without the ball. (Table 1 and 2)

A paired-sampled t-test was conducted to compare the value of the initial velocity without the ball (Velo_NB_Ini) and the value of the final velocity without the ball (Velo_NB_Final) for the subjects. There was no significant difference in the scores of the initial test $(M=3.52136, S D=3.707682)$ and of the final test $(M=4.02504, S D=1.331167)$ conditions; $t(209)=-1.875, p=0.062$. These results suggest that the isometric effort the subjects undergone did not affect the velocity of COP during the handball shooting stance without the ball thought the values are close to a significant level. (Table 1 and 2)

A paired-sampled t-test was conducted to compare the value of the initial length without the ball (Length_NB_Ini) and the value of the final length without the ball (Length_NB_Final) for the subjects. There was no significant difference in the scores of the initial test $(M=35.21333, S D=37.076749)$ and of the final test $(M=40.25028, S D=13.31185)$ conditions; $t(209)=-1.875, p=0.062$. These results suggest that the isometric effort the subjects undergone did not affect the length of COP during the handball shooting stance without the ball thought the values are close to a significant level. (Table 1 and 2)

A paired-sampled t-test was conducted to compare the value of the initial displacement with the ball (Displ_WB_Ini) and the value of the final 
displacement without the ball (Displ_WB_Final) for the subjects. There was no significant difference in the scores of the initial test $(M=0.74487, S D=$ $0.462288)$ and of the final test $(M=0.7908, S D=$ 0.330581 ) conditions; $t(209)=-1.15, p=0.251$. These results suggest that the isometric effort the subjects undergone did not affect the displacement of COP during the handball shooting stance with the ball. (Table 1 and 2)

A paired-sampled t-test was conducted to compare the value of the initial area with the ball (Area_WB_Ini) and the value of the final area with the ball (Area_WB_Final) for the subjects. There was no significant difference in the scores of the initial test $(M=12.50809, S D=47.762378)$ and of the final test $(\mathrm{M}=12.1834, \mathrm{SD}=14.454118)$ conditions; $\mathrm{t}$ $(209)=0.093, p=0.926$. These results suggest that the isometric effort the subjects undergone did not affect the area of COP during the handball shooting stance with the ball. (Table 1 and 2)

A paired-sampled t-test was conducted to compare the value of the initial velocity with the ball (Velo_WB_Ini) and the value of the final velocity with the ball (Velo_WB_Final) for the subjects.

There was no significant difference in the scores of the initial test $(M=3.66422, S D=3.074202)$ and of the final test $(M=4.16338, S D=4.639038)$ conditions; $\mathrm{t}(209)=-1.279, \mathrm{p}=0.202$.

These results suggest that the isometric effort the subjects undergone did not affect the velocity of COP during the handball shooting stance with the ball. (Table 1 and 2)

A paired-sampled t-test was conducted to compare the value of the initial length with the ball (Length_WB_Ini) and the value of the final length with the ball (Length_WB_Final) for the subjects. There was no significant difference in the scores of the initial test $(M=36.64234, S D=30.741812)$ and of the final test $(M=41.63417, S D=46.390038)$ conditions; $\mathrm{t}(209)=-1.279, \mathrm{p}=0.202$. These results suggest that the isometric effort the subjects undergone did not affect the length of COP during the handball shooting stance with the ball. (Table 1 and 2)

\section{Conclusions}

The study of balance stances and their impact over handball techniques should be conducted often to identify the level of influence balance has over the movements. A poor balance may lead to faulty execution of the technique and thus it may affect its result.

Our study concluded that there was a significant difference between the displacement values of COP before and after the isometric effort. This means that the exercises the subjects did impacted the final position of COP at the end of the test. The fact that isometric effort influences the final position of COP means that, after such exercises, the subject can't control the place where his body ends the movement. This may indicate that there will be a translation of the postural vertical line over the course of the technique that may have negative effect on its efficiency.

There were no other significant differences between the initial and final values of the other parameters.

\section{References}

1. Berger R. A. (1965). Isometric training in sports, Indianapolis vol 22, Issue 3, p. 126

2. Toyoshima S., Hoshikawa T., Miyashita M., Oguri T. (1976). Contribution of the body parts to throwing performance, Biomechanics V-B, Komi P.V. Baltimore, MD: University Park Press, p. 169-74

3. Tullos H.S., King J.W. (1973). Throwing mechanism in sports. Orthop Clin North Am, 4(3), p. 709-720

4. Jobe F.W., Moynes D.R., Tibone J.E., Perry J. (1984). An EMG analysis of the shoulder in pitching: a second part. Am J Sports Med, 12, p. 218-220

5. Braatz J.H., Gogia P.P. (1987). The mechanics of pitching, $J$ Orthop Sports Phys Ther, 9:56-69

6. Pappas A.M., Zawacki R.M., McCarthy C.F (1985). Rehabilitation of the pitching shoulder, Am J Sports Med, 13, p. 223-35

7. Joris H.J., Van Muyen A.J., Van Ingen Schenau G.J., Kemper H.C. (1985). Force, velocity and energy flow during the overarm throw in female handball players, J Biomec ,18(6), p. 409-14

8. Eliasz, J. (1999). The Relationships Between Throwing Velocity and Motor Ability Parameters of the High-Performance Handball Players, Dept. of Biomechanics, Institute of Sport, Warsaw, Poland.

9. Çetin E., Balcı N. (2014). The effects of isokinetic performance on accurate throwing in team Handball, Procedia - Social and Behavioral Sciences 174, 6, p. 1872 - 1877.

10. Baştiurea E., Stan Z., Rizescu C., Mihăilă I., Andronic F. (2013). The effect of muscle strength on the capacity of coordination in handball, Procedia - Social and Behavioral Sciences, 137, 8, p. 3 10.

11. Mihăilă I. (2011). Implications of individualized training on growth performance handball sport performance, The Annals of „Dunarea de Jos" University of Galati, Fascicle XV: Physical Education and Sport Management, 1, p. 108-111.

12. Cicma I. T., Mereuţă C. (2012). Effect of physical and technical training on the share of individual and collective tactical actions, in a official game of handball, at the juniors two (Jun. II). Ovidius University Annals, Series: Physical Education and Sport/Science, Movement and Health, 12 (2 supplement), p. 303-308.

13. Andrade M.D.S., De Lira C.A.B., Koffes F.D.C., Mascarin N.C., Benedito-Silva A.A., Da Silva A.C (2012). Isokinetic hamstringsto-quadriceps peak torque ratio: The influence of sport modality, gender, and angular velocity, J Sports Sci, 30, p. 547-553

14. Lund-Hanssen H, Holen K, Hammer S, Gannon J, Engebretsen L. (1996). Isokinetic muscle performance in healthy female 
Timişoara Physical Education and Rehabilitation Journal

handball players and players with a unilateral anterior cruciate ligament reconstruction, Scand J Med Sci Sports, 6, p. 172-175

15. Ronglan L. T., Raastad T., Børgesen A. (2005). Neuromuscular fatigue and recovery in elite female handball players,
Scandinavian Journal of Medicine and Science in Sports, Volume 16, Issue 4, Pages 267-273 